\title{
Internship in Counsellor Training: A Missing Gap in Counsellor Preparation in Nigeria
}

\author{
Charles N. Ugwuegbulam, Phd. \\ School of Education, \\ Alvan Ikoku Federal College of Education, \\ Owerri, Imo State, Nigeria. \\ Mrs Duru Ngozi Damasius, \\ School of Education, \\ Alvan Ikoku Federal College of Education, \\ Owerri, Imo State, Nigeria
}

Doi:10.5296/ijld.v4i2.5564

URL: http://dx.doi.org/10.5296/ijld.v4i2.5564

\begin{abstract}
Counseling in Nigeria emerged as a needed school service and counselor preparation tend to produce counsellors who will work in schools. In the preparation of counsellors, the trainees are exposed to two-six weeks practicum exercise where the trainees have to go on practicum twice a week. This is the picture especially in the preparation of counsellors at the first degree level. At the master's degree level, some institutions provide for a six week intensive practicum exercise in any site of trainee's choice. The picture is not so different at the Ph.D level. There is no provision for proper internship. Given the importance and benefits accruable from having internship component in counselor preparation, this paper calls for its inclusion in the training of counsellors in Nigeria.
\end{abstract}

Keywords: Counsellor Training, Internship, Counselor Preparation, Practicum.

\section{INTRODUCTION}

The provision of formalized counseling service was not part of the provisions the British Government gave to Nigerians in their educational system. Counseling services were provided informally in schools by non-professionals. They were then provided by teachers based on their interests and wealth of knowledge and they were voluntarily done. The training of counselors was not part of the demands of schools in Nigeria until late 1970s. It was in 1977 that guidance and counseling was formally recognized as school service by the Federal Ministry of Education (1977, 1981, 2004). This recognition stimulated the training of profession counselors in tertiary institutions in Nigeria. In 1976/1977 academic year, the Federal Government of Nigeria bought into the training/education of professional counselors. The Federal Ministry of Education made available post graduate scholarships for the education of counselors in some selected Universities, especially those that had mounted a counselor education programme like the University of Ibadan, Benin, Port-Harcourt, etc.

Following the expressed need for professional counselors in our schools, many Universities mounted counselor education programmes, Colleges of Education that were afflicted to such Universities also ran counselor education programmes, for example, the Alvan Ikoku Federal College of Education, Owerri, Imo State ran the counselor education programme of Universities of Nigeria Nsukka to which it affiliated to. 
According to the Unified Tertiary Matriculation Examination Brochure (2012) there are thirty one tertiary institutions (Universities and Colleges of Education) both public and private that train professional counselors at the first degree. Some of the institutions offer counseling degrees as a discipline while some others offer it as combined course with single subject areas of specialization or with educational foundation and administration. For instance, the University of Nigeria Nsukka and its affiliate, Alvan Ikoku Federal College of Education, Owerri, offer degree course in Guidance and Counseling. Although their counseling students study all general education courses like other students from other disciplines. University of Port Harcourt offers Guidance and Counseling degree with one subject combination like English language and Guidance and Counseling. Many Universities offer Masters and Doctorate Degrees in Counseling with no area of specialization apart from University of Ibadan and may be one or two others. However, at the post graduate level, the area of specialization in counseling is inferred from the area each post graduate student domiciled their dissertation by the title and contents. In the course of training the would be counselors, at least the first degree level, there is no provision for internship. This is also true with post graduate training. The provision in counselor education that is close to internship is the counseling practicum exercise. The emphasis on counseling practicum at the first degree level is visible but at the post graduate level, it is either weak or non-existent in some institutions.

This trend is receiving attention as it is about to be changed for the better. At the first degree level, counseling practicum is offered first in the classroom as a taught course of study after which the counseling students are sent out on fieldwork counseling practicum exercise. At this first instance, the trainee is sent out on practicum twice a week for a duration of six weeks. The students are expected to meet with their institution based supervisor every two weeks. At the end of the six weeks counseling practicum exercise, the students expected to submit their counseling practicum packages for a post-mortem evaluation which includes among others the critical review of counseling tapes and materials submitted by students. The above is what is done in most institutions that train counselors. There is no provision or room fro internship in counselor education programme in Nigeria. This is a gap in counselor training in Nigeria in view of the immense importance and merits accruable from such component if included in counselor training in Nigeria.

\section{MEANING OF INTENSHIP IN COUNSELING PROFESSION}

An understanding of the term "internship" will facilitate its meaning when extended to the counseling profession. Internship is a work position which could be non-paid, part or full-time and on-the-job training. (WWW.USA-internship.com/internshipIeames.php?region=6 retrieved 2/11/13). Internship can also be said to be a professional working position that is typically offered to students or inexperienced workers to enable them gain valuable experience and on the job, training while providing the employer with an enthusiastic worker (WWW.Youth.gc.ca/eng/topics/career planning/internship .shm retrieved 2/11/13).

Internship could also be viewed as an opportunity offered by an employer to potential employee, called "interns" to work in an establishment for a fixed, limited period of time. It could be called work placement. From the foregoing internship in counseling profession is that period in the training programme of trainee counselor when they are required to carry out counseling services for a period. This is distinct from the counseling practicum exercise. In internship, a trainee counselor spends some time job shadowing under an experienced professional as the professional carries out his daily works or duties. The intern goes to his/her place of internship and work for a continuous and consolidated period of time for up to six 
months. It is not a situation as in the practicum, where he/she goes to the practicum site on some selected days and goes back to school to continue lectures. (WWW.pot.ed/coun/practicum retrieved on 13/10/2013

\section{PURPOSE OF INTERBSHIP IN COUNSELOR PREPARATION}

Making internship a strong component in counselor preparation has a purpose. The purpose includes but not restricted to the following:

(a) To foster the development of an intern's professional identity as counselors, increase autonomy and confidence in the handing of array of demanding counseling situations commonly faced by practicing counselors, especially beginning counselors.

(b) To develop additional areas of interest in counseling and skills as counselors such as rehabilitation counseling or getting interested in a particular disorder like eating disorder, enuresis, obesity etc.

(c) To develop the knowledge of the counselor's job market arc licensure issues in counseling profession, as well as facilitate the development and sensitivity to ethical and legal issues.

(d) To create the awareness and skills in working with diverse clients and colleagues (www.uh.edu/caps retrieved on 13/10/2013).

(e) To demonstrate the integration of science into practice and interest in continuing education. The continuing education, depending on the quality of training provided and level of course taken, has the potential of improving the knowledge and skills of counseling interns.

\section{BENEFITS OF INTERNSHIP IN COUNSELOR EDUCATION IN NIGERIA}

Presently, there is no provision for internship in counselor education programme in Nigeria. This may be as a result of the nature and types of counselor education programmes run in Nigeria. There seems to be no clear cut area of specialization in counselor education progamme in Nigeria. One's area of specialization is deduced from the area one writes his/her Master's or Doctorate thesis. It is only the University of lbadan that has some areas of specialization in counseling. Besides, none has built in internship programme in their counselor education programme. What they have is counseling practicum exercise. This paper suggests that organized internship programme in counselor education should be part of the counselor education programme at the Masters and Ph.D levels. This is being suggested because of the accruable benefits that are likely to be planned fall outs from the programme. The possible benefits of including internship programme in the whole gamut of post graduate programme in counselor education include but not restricted to be following:

1) It will help gain first hand experience about the counseling field of work. The experiences trainee counselors are likely to gain from the internship exercise are richer than the experience they would have gathered from the two days a week for six weeks counseling practicum experience. This is likely to be because the internship, period is continuous and longer than that of the practicum exercise as well as the fact that the trainee counselor at the post graduate levels are older in age, likely to be more focused on the programme they are pursuing and are more mature. This is especially so because most of those offered admission to study counseling at first degree level come in there as " the only available knee to place their hands on" as there is no other admission possibilities while those enrolling for a post graduate course in counseling made up their minds to study the course and actually go for it.

2) Infusing internship into counselor education programme in Nigeria can 
help inexperienced trainee counselor "to get involved in the workplace and can sometimes lead to job (www.youth.gc.ca/eng/topicescareerplanning/internship.shtml retrieved on 21/11/13)

3) An internship period infused into counselor education programme in Nigeria will offer interns a period of practicum experience. This will be so when they are sent out for internship for a period of not less than six month but a period of one year would be ideal and

better. The internship period should be long enough to allow them work in more than two settings. This follows that the interns are likely to gain experiences in those work settings.

4) It will help interns to earn or gain University academic credit hours. This will be so in a situation where the internship period is made to be part of the counselor education programme prior to graduation. This, for now require the restructuring of counselor education programme in Nigeria by the Nigeria University Commission especially for the first degree programme in counselor education. The individual Universities could restructure their post graduate programmes accordingly to accommodate internship programme. Apart from the above, it will help trainee counselor to be licensed to practice. This will come to be in a situation where it is made a pre-requisite for licensing o counselors as professional.

5) Making internship a component of counselor education in Nigeria will help trainee-counselors to put self forward for forth coming opportunities for paid work during internship. (www.wikijob.co.uk/wiki/internships-what is internship retrieved on 20/11/13). This thinking is informed by the fact that upon good conduct and performance during internship, a trainee counselor may be offered a job by the internship site owners. He/she may also be positively and strongly recommended for employment to prospective employers elsewhere. With the above, it is evident that there are obvious benefits accruable to trainee counselors if internship programme is made a component of counselor education in Nigeria. The counselor' training institutions also stand to gain as the inclusion and proper execution of internship programme will go a long way to add quality to their counselor preparation programme.

\section{IMPORTANCE OF INTERNSHIP IN COUNSELLOR EDUCATION IN NIGERIA}

In the United States of America, Canada, Australia, internship is an integral and essential component in their counselor education programme. It is part of their counselor education programme because they want to produce quality counselors who will render good services. It is only proper and important that internship be made part and parcel of counselors training programme in Nigeria and elsewhere where it is yet to be part of. This is suggested because:

a. Interns are usually under intensive supervision during their period of internship, Interns are supposed to be supervised by experienced and licensed professional counselors in the work setting where $r$ - are. They should keep a record of the works done. This should be properly tagged. They should be having periodic case conferences $\mathrm{w}$ their supervisors on the cases that may be challenging to them. In doing these, interns are expected to progress in their skills development as they are given more responsibilities and autonomy.

b. Interns as less experienced professional, the internship period provides them with further necessary training, supervision and mentoring after graduation. It is suggested that the internship should be situated after formal course of study for first degree in counselor education in universities and before the one year national youth service corps 
scheme, if in Nigeria. The internship period will provide interns with apprenticeship opportunities and consequently help in developing them personally and professionally.

c. The period of Internship encourages interns to formulate hypothesis arid the importance of becoming life-long learners.

d. The internship period can make trainee counselors in Nigeria sensitive to ethnic diversity. The importance of multi-culturalism and multi-ethnicity in counseling can help in the understanding of the importance of cultural issues and individual differences on their therapeutic and professional relationship as well as explore their own beliefs and assumptions regarding cultural and ethnic diversities.

Looking at the issue of a male Christian trying to counsel a female Moslem client, there are issues that are likely to rear up their heads arc consequently prevent the counseling relationship to take place. Fro the foregoing, internship period provides opportunity for interns to read and discourse literature relating to diversity as well as engaging in facilitated exploration and stretching of one's multi-ethnic and cultural lens.

e. The internship period provides counselor interns with on-going opportunities for learning and applying professional ethics and professional standards. It encourages the establishment of professional identity. It provides the opportunity to function at increasing levels of autonomy, confidence and set to make a transition from a position of a counselor interns to a professional (www.coll.Edu/cmfilles retrieved 20/11/13).

The above, mentioned some importance of internship in counselor education. It justifies for its inclusion in Nigeria's counselor education programme after identifying it as a big gap.

\section{SUGGESTIONS}

It is the view of the authors of this article that all counselor education programmes in Africa should have a strong and viable internship component. The internship programme should be properly defined and supervised. In the case of Nigeria, internship should be made part of the counselor education programme. Since counselor education is run from first degree level in Nigeria, internship component should be part of the programme as some of the graduates don't go further to acquire higher degrees in counseling. It is suggested that at the first degree level in counselor education, a three month intensive internship exercise be built in into the programme. The first degree programme in counselor education is already loaded with general education courses offered by those pursuing a B.Ed or B.A (ed) or B.Sc (ed) courses. In view of this, it is suggested that some of the general education courses be removed and the counselor education programme be re-structure so that while the general education students will be going for their first and second teaching practice exercise, the counselors in training should be on their straight three months practicum programme. At this level, the practicum should adopt a generalist dimension where trainees are made to practice in at least two different work settings.

At the post graduate levels in counselor education, each institution has its own programme. The Nigerian University Commission prescribes the minimum standard but individual universities are free to add other counseling courses to make their post graduate counselor education programme of good quality. As at the time of writing, there is no record of any Nigerian University that has internship programme rather, what they have is practicum exercise of not more than fifteen to twenty days contact in a school. The authors wish to suggest that at the master's degree level, there should be a six month intensive internship of two months each in three different work settings. At the Ph.D level authors suggest that a nine months internship period be introduced in trainee counselors programme in two work setting depending on area of specialization of the trainee counselor. The internship periods should be weighted in terms of academic credit loads. At the first degree level, the suggested three months practicum 
period could be weighted 10 credits, while the six and nine months internship periods for masters and Ph.D students could be weighted 20 and 30 credits respectively. The internship should come up after the usual two times a week for six weeks counseling practicum duration. The essence of this is for trainee counselor to transfer and extend their practicum experiences and consequently equipping themselves to get into their preferred profession.

\section{IMPLICATIONS OF INCLUDING INTERNSHIP INTO COUNSELLOR EDUCATION PROGRAMME IN NIGERIA}

The introduction of internship as a component in counselor trairing is a very welcome thing because it has the potency of improving the efficiency of professionally trained counselors but to do that it has its own implications. Some of the implications will be highlighted here.

Presently, internship is not a component of counselor training in Nigeria and many African countries. For it to be introduced, it implies that the counselor educator should organize themselves in their department and critically view the internship programme beyond the usual counseling practicum exercises of twice a week for six weeks.. Apart from the above, counselor education departments should organize professional development workshop for themselves on where and how to post and supervise their interns. This workshop could involve bringing coordinators of internship programmes from elsewhere to run an intensive five day workshop for them. This, it is hoped, will equip them to take off in their own organization of internship programme in their institutions.

In the case of Nigeria where training of counselors start at the first degree level and are made to offer counseling courses alongside with general education courses should be revisited. They should be made to offer counseling course mainly. This will help to build trainees depth of knowledge in counseling. In addition, the admission process should be improved.

The practice where students who are fresh from secondary school are admitted into counselor education programme should be revisited. This is be because counselors should be mature and experienced persons and not "babies" who are barely 18 years old. The practice of offering admission to those holding the Nigeria Certificate in Education diploma should be considered for admission via written aptitude tests and oral interviews. This will help to have trainees who are really interested in studying counseling as a profession and not getting into it because they are not qualified in their personal course preferences and choices.

Counselor education institutions should clearly introduce areas of specializations in counseling like counselor education, rehabilitation, family and marriage, mental health etc. To do this, it implied that their departments should have personnel, lecturers and facilities in those areas their students are likely to specialize. The provision and availability of these things should moderate the number of students to be admitted for each area of specialization.

Furthermore, counselor education institutions should identify and lease with possible internship sites well in advance before sending their interns to serve in such site. The sites should be such that knows their roles and responsibilities in the internship business. The sites should have facilities to further the training of the interns. In addition, counselor education institutions should relate professionally and strongly with the sites where their trainees will be posted to for their internship experience.

Prior to sending trainee counselor out on internship, their institutions should have exposed them to the type of facilities to be used at the different internship sites. This is to make the interns function better at their sites instead of experiencing shock. Achieving this is a far cry as most counselor training institutions don't have functional counseling laboratories as well as materials and ICT facilities to practice with. Serious taught should be given to the above so that the attendant issues can be addressed. 


\section{Macrothink}

\section{CONCLUSION}

This paper attempts to suggest the improvement of counselor education in Nigeria by including a strong and effective internship component. Presently, what is on ground in terms of counselor education in Nigeria is appreciable but can be built upon. This paper merely identified a necessary missing component in counselor education and calls for its inclusion especially now that the counseling Association of Nigeria (CASSON), the strongest counseling association in Africa with very large and active members is finalizing its certificate, licensure and legalization process.

\section{References}

Adegoke, A.A. and Culbreth, J.R.(1998). Counselor preparation in Nigeria and the United States of America, Vol 6 no1, Pp117-132.

Federal Republic of Nigeria, (1977) National Policy on education. Yaba: NERDC press. Federal Republic of Nigeria, (1981) National Policy on education. Yaba: NERDC press. Federal Republic of Nigeria,(2004). Naational Policy on Education. Yaba: NERDC press. Unified tertiary matriculation examination board (2012) Brochure for students. www.abu/edu.nig/category/wwprogdatail/php/pd-108\&t=a\&ad=education $\&$ did=arts\%science edu retrieved on $4 / 11 / 2013$

www.pot.ed/coun/practicum retrieved on 13/10/2013.

www.cou.edu/cmfiles/docs/counsellingpraticum/internshipmanual.pdt retrieved on 4/11/2013 www.uh.edu/caps/clinical-training/apa-internship.html retrieved on 1/12/2013 www.usa-internship.com/internshiplearns.phpregion6 retrieved 2/11/2013 www.youth.gc.ca/eng/topic/careerplanning/internship.shtml retrieved 2/11/2013 www.pot.ed/coun/practicum retrieved 13/10/2013 www.youth.gc.ca/eng/topics/careerplkanning/internship.shtml retrieved on $2 / 12 / 2013$ www.wikijobs.co.uk/wiki/internship retrieved on 20/11/2013 www.cool.edu/cmfiles retrieved on 20/11/2013 